\title{
KEANEKARAGAMAN SPESIES LALAT (DIPTERA) DAN BAKTERI PADA TUBUH LALAT DI TEMPAT PEMBUANGAN AKHIR SAMPAH (TPA) DAN PASAR
}

\author{
Yunita Panca Putri \\ Program Studi Pengelolaan Lingkungan Jurusan Biologi Lingkungan \\ Pasca Sarjana Universitas Sriwijaya \\ Email: yunita_pp12@yahoo.co.id
}

\begin{abstract}
ABSTRAK
Lalat adalah jenis Arthropoda yang termasuk ke dalam ordo Diptera. Sebagai vektor mekanis lalat membawa bibit-bibit penyakit melalui anggota tubuh seperti rambut-rambut pada kaki, badan, sayap dan mulutnya. Beberapa penyakit yang dapat ditularkan melalui makanan oleh lalat ini adalah disentri, kholera, typhoid, diare dan gatal-gatal pada kulit. berbagai macam bakteri terutama bakteri enterik seperti disentri basiler (Shigella), kolera, typhoid, paratyphoid (Salmonella),anthrax dan berbagai macam kokus. (Suraini, 2011). Penelitian ini dilakukan pada bulan Januari sampai Mei 2015. Lokasi pengambilan sampel lalat di Pasar Induk Jakabaring Palembang dan TPA Sukawinatan Palembang. Di Pasar diperoleh 5 spesies lalat, yaitu Musca domestica, Chrysomia megacephala, Lucilia sp, Sarcophaga sp dan Fannia sp. Di TPA diperoleh 4 spesies lalat, yaitu Musca domestica, Chrysomia megacephala, Lucilia sp, dan Fannia sp. Dari isolasi bakteri dari permukaan luar tubuh lalat di Pasar diperoleh bakteri dari genus Proteus, Salmonella, Providencia dan Citrobacter. Sedangkan di TPA diperoleh bakteri dari genus Salmonella, Providencia, Citrobacter, Escherichia, Enterobacter dan Vibrio.
\end{abstract}

Kata kunci : jenis lalat (Diptera), Tempat Pembuangan Sampah Akhir (TPA), Pasar, Bakteri.

\begin{abstract}
The fly is a type of arthropod belonging to the order Diptera. As mechanical vectors of flies carrying germs through limbs like hairs on the legs, body, wings and mouth. Some diseases that can be transmitted through food by flies are dysentery, cholera, typhoid, diarrhea and itching of the skin. various kinds of bacteria, especially enteric bacteria such as bacillary dysentery (Shigella), cholera, typhoid, paratyphoid (Salmonella), anthrax and various cocci. (Suraini, 2011). This research was conducted in January to May 2015. The location of sampling flies in the Market Master and landfill Sukawinatan Jakabaring Palembang Palembang. The market gained 5 species of flies, which Musca domestica, Chrysomia megacephala, Lucilia sp, Sarcophaga sp and Fannia sp. The TPA is obtained four species of flies, which Musca domestica, Chrysomia megacephala, Lucilia sp and Fannia sp. From the isolation of bacteria from the outer surface of the fly's body in the Market acquired bacteria of the genus Proteus, Salmonella, Providencia and Citrobacter. While in the TPA is obtained bacteria of the genus Salmonella, Providencia, Citrobacter, Escherichia, Enterobacter, and Vibrio.
\end{abstract}

Keywords: types of flies (Diptera), landfill (TPA), Market, bacteria. 


\section{PENDAHULUAN}

Lalat adalah jenis Arthropoda yang termasuk ke dalam ordo Diptera. Beberapa spesies lalat merupakan spesies yang paling berperan dalam masalah kesehatan masyarakat, yaitu sebagai vektor penularan penyakit. Sebagai vektor mekanis lalat membawa bibit-bibit penyakit melalui anggota tubuh seperti rambut-rambut pada kaki, badan, sayap dan mulutnya.

Lalat untuk mempertahankan kehidupannya dan daya tariknya terhadap bau-bau yang busuk menuntun lalat untuk mencari tempattempat yang kotor untuk mencari sesuatu yang dapat dimakannya. Biasanya tempattempat tersebut adalah tempat yang banyak berhubungan dengan aktivitas manusia. Lalat banyak terdapat di berbagai habitat, diantaranya adalah pada Tempat Pembuangan Akhir Sampah (TPA) dan Pasar.

Dari penelitian Suraini (2011) di TPA kota Padang, diperoleh isolat bakteri dari permukaan luar tubuh lalat $M$. domestica dan lalat $C$. megacephala didapatkan jenis bakteri Enterobacter aerogenes, Escherichia coli, Proteus sp, Bacillus sp, Serratia marcescens. Selanjutnya dari penelitian Hastutiek dan Fitri (2007), dari tubuh lalat Musca domestica ditemukan bakteri Acinetobacter sp, Cirtobacter freundii, Enterobacter aerogenes, Enterobacter agglomerans, Hafnia alvei, Klebsiella pneumoniae, Morganella morganii, Proteus vulgaris, Pseudomonas sp, Salmonella sp., Listeria sp., Shigella sp.,Vibrio cholera, Staphylococcus aureus dan M. leprae.

Di kota Palembang saat ini satu-satunya TPA adalah TPA Sukawinatan. Menampung semua sampah yang berasal dari berbagai sumber sampah di kota Palembang, seperti pemukiman penduduk, pasar, perkantoran/komersial, jalan dan fasilitas umum. Sampah yang menumpuk merupakan sumber bau tidak sedap yang memberikan efek buruk bagi daerah di sekitarnya. bau tak sedap di TPA juga timbul akibat penutupan sampah yang tidak dilakukan dengan baik. Sarana pengangkutan yang tidak tertutup dengan baik juga sangat berpotensi menimbulkan masalah bau di sepanjang jalur yang dilalui, terutama akibat bercecerannya air lindi dari bak kendaraan. Prasarana dan sarana pengumpulan yang terbuka sangat potensial menghasilkan lindi terutama pada saat turun hujan. Aliran lindi ke saluran atau tanah sekitarnya akan menyebabkan terjadinya pencemaran.

Pasar Jakabaring merupakan pasar induk di kota Palembang, karena menyuplai sayur, buah maupun ikan/daging dalam jumlah banyak dari berbagai daerah di kota Palembang, sehingga para pedagang dapat membeli dalam jumlah banyak kebutuhan dengan harga yang lebih murah, untuk kemudian dijual kembali. Pasar merupakan tempat manusia melakukan aktivitas jual beli untuk mendapatkan berbagai jenis bahan makanan, seperti ikan, daging, sayur dan buah sehingga dari aktivitas tersebut akan menghasilkan sampah dan menjadikan lingkungan pasar menjadi kotor dan bau.

Penelitian yang berkaitan dengan jenis-jenis lalat sangat diperlukan dalam usaha untuk pengendalian wabah penyakit-penyakit terutama yang ditularkan melalui lalat pada manusia. Penelitian sebelumnya, Suraini (2011) mendapatkan 2 jenis lalat (Diptera) di tempat pembuangan akhir sampah (TPA) Kota Padang, yaitu Musca domestica dan Chrysomya megacepha. Sementara itu Yuriatni (2011), mendapatkan 6 jenis lalat yaitu Musca domestica, Chrysomya megacephala, Fania canicularis, Calliphora sp., Lucilia sp. dan Sarcophaga sp. Selanjutnya hasil penelitian Putri dkk., (2013), mengenai keanekaragaman lalat (Cyclorrapha: Diptera) pada lokasi penjualan ikan segar di Kota Padang ditemukan 5 species lalat yaitu Musca domestica, Chrysomya megacephala, Lucillia sp., Calliphora sp., Sarcophaga sp dan species yang paling dominan adalah Musca domestica.

Berdasarkan uraian diatas, perlu dilakukan penelitian yang mengkaji keterkaitan antara bakteri pada lalat, dimana Tempat Pembuangan Akhir Sampah (TPA) dan Pasar dijadikan lokasi yang tepat untuk penelitian. Karena terdorong oleh beberapa masalah tersebut maka penulis tertarik untuk melakukan penelitian tentang “ Keanekaragaman Spesies Lalat (Diptera) 
dan Bakteri Pada Tubuh Lalat di Tempat Pembuangan Akhir Sampah (TPA) dan Pasar".

Penelitian ini bertujuan untuk mengkaji keanekaragaman spesies lalat (Diptera) ditinjau dari indeks keanekaragaman, indeks dominansi, dan indeks Evennes di Tempat Pembuangan Akhir Sampah (TPA) Sukawinatan Palembang dan Pasar Induk Jakabaring Palembang. Mengidentifikasi bakteri pada tubuh lalat yang diperoleh di Tempat Pembuangan Akhir Sampah (TPA) Sukawinatan Palembang dan Pasar Induk Jakabaring Palembang.

\section{METODOLOGI PENELITIAN}

Penelitian akan dilaksanakan pada bulan Januari sampai bulan Mei 2015. Tempat pengambilan sampel adalah Tempat Pembuangan Akhir Sampah (TPA) Sukawinatan Palembang dan Pasar Induk Jakabaring Kota Palembang. Tempat penelitian adalah Laboratorium Entomologi jurusan Hama Penyakit Tanaman Fakultas Pertanian UNSRI Indralaya dan Laboratorium Mikrobiologi Jurusan Biologi FMIPA UNSRI Indralaya.

Alat-alat yang digunakan pada penelitian ini meliputi jaring penangkap lalat (insect net), botol koleksi, pinset, kamera, kaliper, mikroskop, autoclaf, inkubator, oven, mikroskop, optilab, timbangan analitik, petridish, cawan petri, erlenmeyer, tabung reaksi, jarum ose, jarum inokulasi, bunsen, magnetic stirrer (pengaduk magnet), kompor listrik, kulkas, kertas pembungkus, karet, alat tulis, masker, kaca objek, kaca penutup, tabung reaksi, tabung durham, rak tabung reaksi dan pipet tetes. Bahan-bahan yang diperlukan adalah Nutrient Agar (NA), larutan garam fisiologis ( $\mathrm{NaCl} 0,9 \%)$, aquades, alkohol 70\%, zat warna Kristal violet, larutan Iodine, safranin, minyak emersi, larutan malachite green, medium agar pati, medium nutrient gelatin, medium Nutrient Broth (NB), fenol merah, gula (glukosa,laktosa, dan sukrosa), larutan reagen kovac's, medium Simmon's Citrate agar, kertas umpan berperekat, medium MR-VP, larutan metil merah, larutan Barrit A dan Barrit B, medium TSIA, dan larutan $\mathrm{H}_{2} \mathrm{O}_{2}$

\section{Penangkapan lalat}

Penangkapan lalat dengan menggunakan insect net, diambil sebanyak 3x penangkapan. Dilakukan 1 minggu sekali, selama 3 minggu, dan menggunakan kertas umpan berperekat yang diletakkan pada setiap titik pengambilan sampel di masingmasing lokasi penelitian dari pukul 08.00 WIB sampai pukul 10.00 WIB. Untuk keperluan identifikasi lalat, digunakan kunci identifikasi menggunakan buku Borror et al., (1992) dan Kalshoven (1981). Identifikasi lalat dikerjakan secara makroskopis dan mikroskopis (dengan Stereomikroskop) dan didasarkan pada semua gambaran dalam struktur anatomis luar tubuh lalat. identifikasi bakteri berdasarkan buku Bergey's Manual of Determinative Bacteriology $8^{\text {th }}$ Edition (Gibbons and Buchanan, 1974), Bergey's Manual of Determinative Bacteriology $9^{\text {th }}$ Edition (Holt et al., 1994).

\section{HASIL DAN PEMBAHASAN}

Tabel 1. Famili, Spesies dan jumlah individu lalat (Diptera) yang ditemukan di Pasar Induk Jakabaring Palembang (3x penangkapan).

\begin{tabular}{|c|c|c|c|c|c|c|c|}
\hline \multirow[t]{2}{*}{ Family } & \multirow[t]{2}{*}{ Spesies } & \multicolumn{5}{|c|}{$\begin{array}{c}\text { Pasar Induk } \\
\text { Jakabaring } \\
\text { Palembang } \\
\end{array}$} & \multirow[t]{2}{*}{ Total } \\
\hline & & $\begin{array}{l}\mathrm{s} \\
\mathrm{a} \\
\mathrm{y} \\
\mathrm{u} \\
\mathrm{r}\end{array}$ & $\begin{array}{l}\mathrm{i} \\
\mathrm{k} \\
\mathrm{a} \\
\mathrm{n}\end{array}$ & $\begin{array}{l}\mathrm{d} \\
\mathrm{a} \\
\mathrm{g} \\
\mathrm{i} \\
\mathrm{n} \\
\mathrm{g}\end{array}$ & $\begin{array}{l}\mathrm{b} \\
\mathrm{u} \\
\mathrm{a} \\
\mathrm{h}\end{array}$ & $\begin{array}{l}\mathrm{i} \\
\mathrm{k} \\
\mathrm{a} \\
\mathrm{n}\end{array}$ & \\
\hline $\begin{array}{l}\text { Calliphor } \\
\text { idae }\end{array}$ & $\begin{array}{l}\text { Chrysomya } \\
\text { megacephala }\end{array}$ & - & $\begin{array}{l}2 \\
8\end{array}$ & $\begin{array}{l}1 \\
9\end{array}$ & - & 8 & 56 \\
\hline Muscidae & $\begin{array}{l}\text { Musca } \\
\text { domestica. }\end{array}$ & $\begin{array}{l}3 \\
2\end{array}$ & $\begin{array}{l}3 \\
0\end{array}$ & $\begin{array}{l}1 \\
8\end{array}$ & $\begin{array}{l}1 \\
4\end{array}$ & $\begin{array}{l}3 \\
3\end{array}$ & 127 \\
\hline $\begin{array}{l}\text { Calliphor } \\
\text { idae }\end{array}$ & Lucilia sp.. & - & $\begin{array}{l}1 \\
6\end{array}$ & 5 & - & - & 21 \\
\hline $\begin{array}{l}\text { Sarcopha } \\
\text { gidae }\end{array}$ & $\begin{array}{l}\text { Sarcophaga } \\
\text { sp. }\end{array}$ & - & - & - & - & 2 & 2 \\
\hline $\begin{array}{l}\text { Muscida } \\
\text { e }\end{array}$ & Fannia sp. & 7 & 2 & 6 & 5 & 6 & 26 \\
\hline Jumlah & & $\begin{array}{l}3 \\
9\end{array}$ & $\begin{array}{l}7 \\
6\end{array}$ & $\begin{array}{l}4 \\
8\end{array}$ & $\begin{array}{l}1 \\
9\end{array}$ & $\begin{array}{l}4 \\
9\end{array}$ & 232 \\
\hline
\end{tabular}

Sumber : Data penelitian. 
Tabel 2. Famili, Spesies dan jumlah individu lalat (Diptera) yang ditemukan di TPA

Sukawinatan Palembang ( $3 x$ penangkapan).

\begin{tabular}{|c|c|c|c|c|c|c|c|}
\hline Family & Spesies & TPA & Sukav & inatan & Palem & jang & $T$ \\
\hline & & $\begin{array}{l}\text { Plot } \\
\text { I }\end{array}$ & $\begin{array}{l}\text { Plot } \\
\text { II }\end{array}$ & $\begin{array}{l}\text { Plot } \\
\text { III }\end{array}$ & $\begin{array}{l}\text { Plot } \\
\text { IV }\end{array}$ & $\begin{array}{l}\text { Plot } \\
\text { V }\end{array}$ & \\
\hline Calliphoridae & $\begin{array}{l}\text { Chryso } \\
\text { mya } \\
\text { megacep } \\
\text { hala }\end{array}$ & 11 & 9 & 14 & 8 & 11 & 53 \\
\hline Muscidae & $\begin{array}{l}\text { Musca } \\
\text { domestic } \\
\text { a. }\end{array}$ & 68 & 220 & 366 & 211 & 165 & \\
\hline
\end{tabular}

\begin{tabular}{llllllll} 
Calliphoridae & $\begin{array}{l}\text { Lucilia } \\
\text { sp.. }\end{array}$ & $\mathbf{3}$ & $\mathbf{5}$ & $\mathbf{1 6}$ & $\mathbf{5}$ & $\mathbf{5}$ & 34 \\
\hdashline Sarcophagidae & $\begin{array}{l}\text { Sarcoph } \\
\text { aga sp. }\end{array}$ & - & - & - & - & - & 0
\end{tabular}

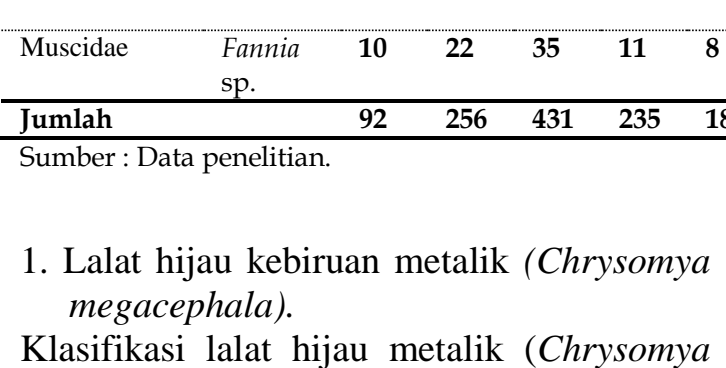
megacephala) menurut Borror et al., (1992) sebagai berikut:

$\begin{array}{ll}\text { Kingdom } & \text { : Animalia } \\ \text { Phylum } & \text { : Arthropoda } \\ \text { Class } & \text { : Hexapoda } \\ \text { Ordo } & \text { : Diptera } \\ \text { Family } & \text { : Calliphoridae } \\ \text { Genus } & \text { : Chrysomya } \\ \text { Spesies } & : \text { Chrysomya megacephala }\end{array}$
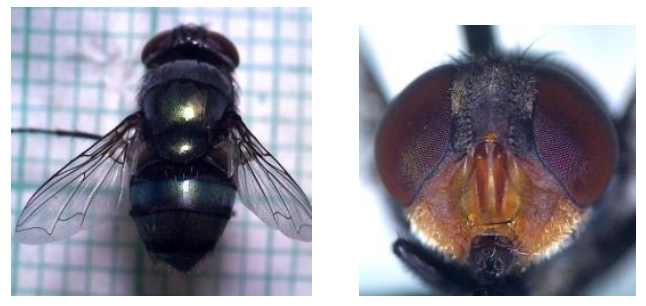

Deskripsi :

Dari pengamatan dan pengukuran yang telah dilakukan tanda-tanda morfologi Chrysomya megacephala yaitu warna tubuh hijau kebiruan metalik, panjang tubuh 9,5 mm, panjang venasi sayap $5 \mathrm{~mm}$, thorax berwarna hijau metalik kecokelatan, permukaan tubuh tertutup dengan bulu-bulu pendek keras dan jarang letaknya. Abdomen berwarna hijau metalik mempunyai garisgaris transversal. Pada bagian mulutnya bewarna kuning. Mata berukuran besar dan berwarna merah gelap. Sayap jernih dengan guratan urat-urat yang jelas. Ciri-ciri menurut (Borror et al., 1992), tubuh To berwarna hijau metalik, mempunyai arista sungut plumosa pada ujungnya. Thoraks berwarna hijau metalik kecokelatan (Suraini, 2011).

${ }_{103}$ 2.Lalat rumah (Musca domestica).

Klasifikasi lalat hijau (Musca domestica) menurut Borror et al., (1992) sebagai berikut:

Kingdom : Animalia

Phylum : Arthropodagm,.

Class : Insecta

Ordo : Diptera

: Muscidae

: Musca

: Musca domestica.

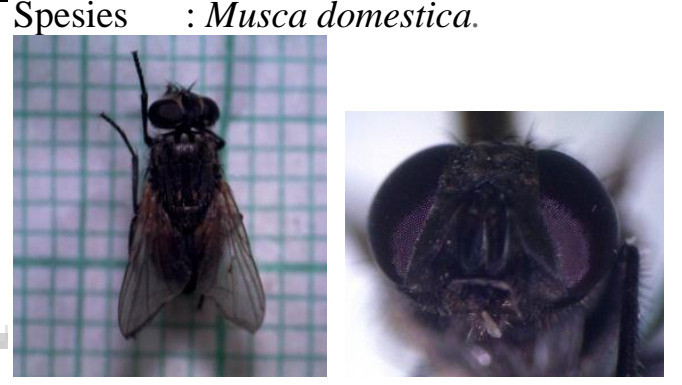

Deskripsi:

Dari pengamatan dan pengukuran yang telah dilakukan tanda-tanda morfologi tubuh lalat $M$. domestica yaitu warna tubuh abu-abu kehitaman, pada bagian abdomen berwarna kuning orange dan ujungnya coklat kehitaman. Pada bagian permukaan atas thorax terdapat 4 garis berwarna hitam. Panjang tubuh tubuh $7 \mathrm{~mm}$ dan panjang venasi sayap $6 \mathrm{~mm}$. Kepalanya besar berwarna coklat gelap, mata besar menonjol dan terpisah. Sayap tipis serta tembus cahaya, dan berpangkal kuning. Ciri-ciri yang ditemukan menurut Suraini (2011), tubuh berwarna abu-abu kehitaman. Bagian dorsal dari thorax mempunyai 4 garis hitam longitudinal. Abdomen ditandai dengan warna dasar kekuningan serta didapatkan garis hitam di bagian median (Hastutiek, 2007).

3. Lalat hijau metalik (Lucilia sp).

Klasifikasi lalat hijau metalik (Lucilia sp.) menurut Borror et al., (1992) sebagai berikut:

Kingdom : Animalia 


$\begin{array}{ll}\text { Phylum } & \text { : Arthropoda } \\ \text { Class } & \text { : Insecta } \\ \text { Ordo } & \text { : Diptera } \\ \text { Famili } & \text { : Calliphoridae } \\ \text { Genus } & \text { : Lucilia } \\ \text { Spesies } & \text { : Lucilia } \text { sp.. }\end{array}$

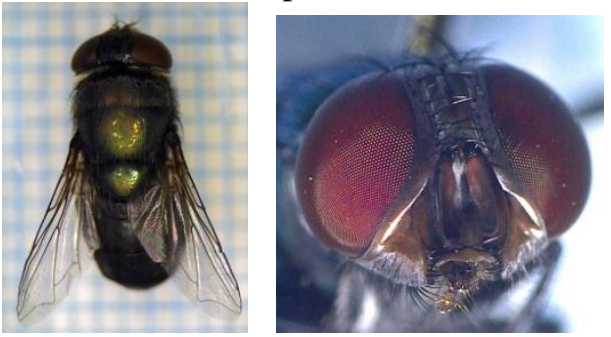

Deskripsi:

Dari pengamatan dan pengukuran yang telah dilakukan tanda-tanda morfologi tubuh lalat Lucilia sp. yaitu warna tubuh hijau metalik, panjang tubuh lebih kurang 9,5 mm, panjang venasi sayap $6,5 \mathrm{~mm}$, thorax dan abdomen bewarna hijau metalik. Ciri-ciri menurut Laksmita dkk., (2013), tubuh berwarna hijau metalik, mata berwarna merah. Berwarna hijau metalik (Borror et al., 1992).

\section{Lalat abu-abu (Sarcophaga sp.)}

Klasifikasi lalat abu-abu (Sarcophaga sp.) menurut Borror et al., (1992) sebagai berikut:

$\begin{array}{ll}\text { Kingdom } & \text { : Animalia } \\ \text { Phylum } & \text { : Arthropoda } \\ \text { Class } & \text { : Insecta } \\ \text { Ordo } & \text { : Diptera } \\ \text { Famili } & \text { : Sarcophagidae } \\ \text { Genus } & \text { : Sarcophaga } \\ \text { Spesies } & \text { : Sarcophaga } \text { sp. }\end{array}$
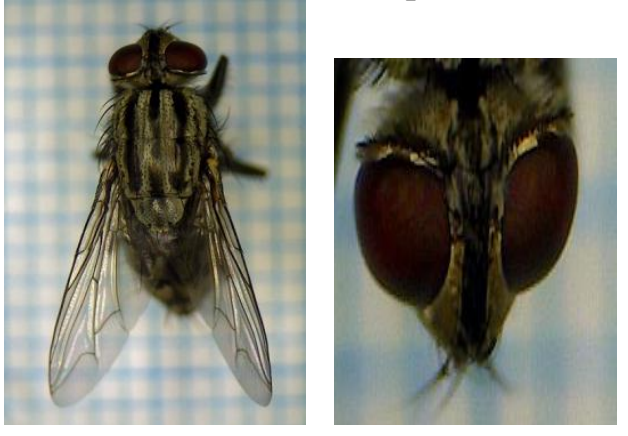

Deskripsi:

Dari pengamatan dan pengukuran yang telah dilakukan tanda-tanda morfologi tubuh lalat Sarcophaga sp. Tubuh berwarna abu-abu, dengan bercak-bercak hitam atau dengan garis-garis hitam memanjang pada thorax, dan abdomen memiliki corak seperti papan catur diperoleh panjang tubuh $9,5 \mathrm{~mm}$ dan panjang venasi sayap $8 \mathrm{~mm}$. Ciri-ciri menurut Lilies (1991), tubuh berwarna hitam dengan strip pada thorax berwarna abu-abu. Mempunyai tiga garis gelap pada bagian thorax, perutnya mempunyai corak seperti papan catur (Putri dkk., 2013).

\section{Lalat kecil (Fannia sp).}

Klasifikasi lalat kecil (Fannia sp) menurut Borror et al., (1992) sebagai berikut:

Kingdom : Animalia

Phylum : Arthropoda

Class : Insecta

Ordo : Diptera

Famili : Muscidae

Genus : Fannia

Spesies :. Fannia sp.
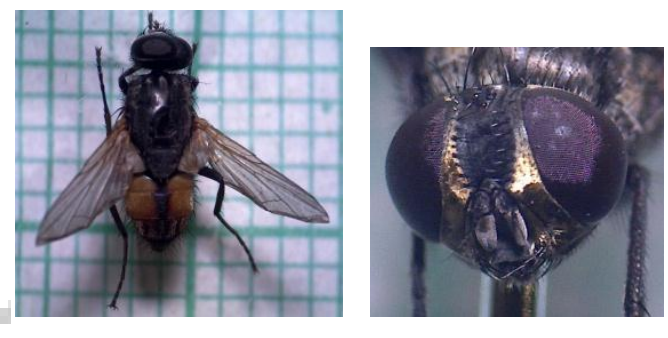

Deskripsi:

Dari pengamatan dan pengukuran yang telah dilakukan diperoleh panjang ukuran tubuh 7 $\mathrm{mm}$ dan venasi sayap $4,5 \mathrm{~mm}$. Lalat ini kelihatan seperti lalat rumah tetapi ukuran jauh lebih kecil. Berkembangbiak di kotoran manusia dan hewan dan juga dibagianbagian tumbuhan yang membusuk, misalnya di tumpukan rumput yang membusuk (Borror et al., 1992).

Pada tabel 1 diperoleh bahwa spesies lalat yang ditemukan pada lokasi Pasar Induk Jakabaring Palembang ada 5 spesies yaitu Chrysomya megacephala, Musca domestica , Lucilia sp, Sarcophaga sp dan Fannia sp. Sedangkan dari tabel 2 spesies lalat yang ditemukan pada lokasi TPA Sukawinatan Palembang ada 4 spesies yaitu Chrysomya megacephala, Musca domestica, Lucilia sp, dan Fannia sp. Di Pasar Induk Jakabaring Palembang ditemukan spesies lalat lebih banyak dibandingkan di TPA Sukawinatan Palembang karena di lokasi pasar menyediakan makanan yang berbeda-beda sehingga jenis lalat yang ditemukan lebih beragam. Dari ke-5 plot di lokasi pasar, 
spesies lalat yang selalu ditemukan yaitu Musca domestica dan Fannia sp dari Famili Muscidae. Menurut Lilies (1991), Famili Muscidae dapat ditemukan di semua tempat atau bersifat 84riteria84tan. Didominasi oleh Musca domestica dengan total jumlah terbanyak yaitu 127 ekor. Hal ini disebabkan Musca domestica termasuk hewan omnivorous (pemakan segala). Lalat ini juga mempunyai daya reproduksi yang cukup tinggi dan dapat menghasilkan beberapa generasi dalam 1 tahun (Astuti dan Pradani, 2010). Secara keseluruhan Musca domestica mampu menghasilkan telur dalam jumlah yang cukup besar, lebih kurang 2000 butir. Dengan jumlah tersebut Musca domestica mampu membentuk 10-12 generasi dalam satu musim (Hastutiek, 2007). Pada daerah tropis, Musca domestica membutuhkan waktu 8- 10 hari pada suhu $30^{\circ} \mathrm{C}$ dalam satu siklus hidupnya, dari telur, larva, pupa dan dewasa (Sigit dan Hadi, 2006).

Chrysomya megacephala banyak ditemukan di plot penjualan daging disebabkan karena, plot penjualan daging memiliki daya dukung bagi kelangsungan hidup lalat tersebut, sehingga menarik lalat untuk berkunjung. Lalat akan mengunjungi suatu tempat jika ada sumber makanan dan tempat meletakkan telurnya. Lalat $C$. megacephala meletakkan telur dalam daging busuk, ikan, tempat sampah, dan bangkai. Sedangkan lalat rumah menyukai sayuran, karbohidrat dan sedikit protein (Kartikasari, 2008) . Lucilia sp hanya ditemukan di plot jualan ikan segar dan daging, dengan jumlah terbanyak terdapat di plot jualan ikan segar. Ini dikarenakan plot ikan segar dan daging mendukung untuk hidup dan berkembangbiak lalat, disekitar lokasi penjualan ikan segar juga terdapat genangan air, tumpukan limbah ikan, kondisi demikian dapat menyebabkan lokasi penjualan ikan segar menjadi kotor dan lembab, yang akhirnya juga mendukung perkembangan hidup lalat. Selanjutnya Sarcophaga sp hanya ditemukan 2 ekor di plot jualan ikan asin. Sarcophaga sp tertarik pada daging atau bangkai, dan juga dikenal menyebabkan myiasis pada makhluk hidup. Tertarik pada mayat hampir di semua situasi, terpapar ataupun terlindung dari matahari, lingkungan basah ataupun kering, di dalam ataupun luar ruangan (Wahyu, 2009).
Pada lokasi TPA Sukawinatan Palembang ditemukan 4 spesies lalat pada setiap plot (tabel 2). Hestiningsih et al., (2003) mengatakan Tempat Pembuangan Akhir sampah merupakan tempat ditemukannya fauna lalat dan merupakan tempat berbagai agen penyebab infeksi. Sama halnya pada lokasi Pasar Jakabaring Palembang, spesies lalat yang ditemukan paling banyak yaitu Musca domestica. Musca domestica berkembang biak dalam kotoran dari semua jenis dan seringkali sangat banyak (Borror $e t$ al., 1992).

Plot I merupakan plot sampah yang sudah lama dan jauh dari lubang dumping. Tekstur sampah lebih kering dan tidak terlalu mengeluarkan bau yang menyengat sehingga keberadaan lalat tidak begitu banyak. Plot II dan plot IV merupakan plot sampah yang juga jauh dari lubang dumping namun plot ini msh mengalami pengerukan sampah oleh buldozer sehingga sampah teraduk dan mengeluarkan bau yang menyengat dan mengundang lalat untuk datang lebih banyak. Plot III merupakan plot yang paling dekat dengan lubang dumping, seringkali mengalami pengerukan oleh buldozer, sehingga mengeluarkan bau yang sangat menyengat dan sampah yang baru akan mengandung makanan yang lebih banyak bagi lalat sehingga tak mengherankan jika jumlah lalat yang ditemukan pada plot ini sangat banyak dibandingkan plot-plot lainnya. Sementara plot V merupakan plot sampah yang lama dan tidak mengalami pengerukan oleh buldozer. Plot ini banyak digunakan pemulung untuk membuat pondokan dan meletakkan barang-barang bekas hasil pencarian. Lalat ditemukan pada saat datang dan hinggap di pondokan dan diantara barang-barang bekas seperti kantong plastik, botol dan gelas minuman.

Dari ke-4 spesies lalat yang ditemukan pada TPA. Lucilia sp ditemukan paling sedikit dibandingkan spesies lainnya. Hal ini dikarenakan daya reproduksinya yang tidak terlalu tinggi. Satu kali bertelur familia ini sekitar 43-47 butir. Satu siklus hidup dari genus Lucilia di perairan memerlukan waktu rata-rata 20,5 hari sedangkan di daratan memerlukan waktu rata-rata 17,5 hari ( Laksmita, 2013). Spesies lalat Sarcophaga sp tidak ditemukan di TPA Sukawinatan. 
Hal ini kemungkinan dikarenakan tidak tersedianya cukup makanan bagi lalat tersebut. Sarcophaga sp sangat menyukai adanya darah dalam makanan, karena akan mempengaruhi produksi telur dan mempercepat maturasi seksual. Sarcophaga sp menyukai daging atau bangkai untuk kelangsungan hidupnya (Wahyu, 2009).

Dari analisis yang dilakukan (lampiran 1, tabel. 3) dapat dilihat bahwa nilai Indeks Keanekaragaman $\bar{H}$ pada plot ikan sebesar 1,16 dan plot daging sebesar 1,23. Angka ini menunjukkan pada kedua plot tersebut tingkat keanekaragaman spesies lalat yang ditemukan cukup besar/sedangs. Menurut Odum (1998), _ kriteria indeks keanekaragaman $\bar{H}<1$ berarti keanekaragaman kecil dan kestabilan komunitas rendah. $1 \leq \bar{H} \leq 3=$ Keanekaragaman sedang dan kestabilan komunitas sedang. $\bar{H}>3$ = Keanekaragaman besar dan kestabilan komunitas tinggi. Hal ini disebabkan pada plot ikan dan plot daging memiliki daya dukung bagi kelangsungan hidup lalat. Lalat akan mengunjungi suatu tempat jika ada sumber makanan dan tempat meletakkan telurnya (Yuriatni, 2011). Sedangkan pada plot sayur dan buah diperoleh nilai Indeks keanekaragaman sebesar 0,47 dan 0,58. Hal ini berarti tingkat keanekaragaman spesies lalat pada kedua plot kecil. Berdasarkan tabel1. Dapat dilihat, dari 5 spesies lalat yang diperoleh di lokasi Pasar Induk Jakabaring Palembang. Plot sayur dan plot buah hanya ditemukan 2 spesies lalat dari family yang sama, yaitu Musca domestica dan Fannia sp. Sementara pada plot ikan asin nilai indeks keanekaragamannya sebesar 0,95 (mendekati 1), ini berarti tingkat keanekaragaman spesies lalat yang ditemukan pada plot ini lebih beragam dibandingkan plot sayur dan buah.

Perhitungan Indeks Dominansi (C) pada plot ikan, plot daging, dan plot ikan asin masingmasing sebesar 0,66, 0,68 dan 0,50. Kriteria $\mathrm{C}>0,5=$ dominansi tinggi, Kriteria $\mathrm{C}<0,5$ $=$ dominansi rendah (Odum, 1998). Ini menunjukkan bahwa pada ketiga plot tersebut memiliki 1 spesies lalat yang mendominasi. Hal ini dapat dilihat dari tabel 1. Bahwa salah satu spesies lalat pada masing-masing plot ditemukan jumlah yang lebih banyak dibandingkan spesies lalat lainnya. Sedangkan pada plot sayur dan plot buah dengan nilai indeks dominansi sebesar 0,29 dan 0,39. Ini berarti pada kedua plot tidak ada spesies lalat yang mendominansi. Keanekaragaman identik dengan kestabilan suatu ekosistem, jika keanekaragaman suatu ekosistem tinggi, maka kondisi ekosistem tersebut cenderung stabil (Odum, 1998).

Nilai indeks Evenness (E) pada plot sayur sebesar 0,80, plot ikan sebesar 0,79, plot daging sebesar 0,86, plot buah sebesar 0,89 dan plot ikan asin sebesar 0,65. Kondisi ini, menunjukkan sedikit saja perbedaan. Menurut Odum (1998), bahwa indeks E > 0,6 menunjukkan keseragaman tinggi. Sehingga dapat diasumsikan bahwa kelimpahan populasi spesies lalat pada masing-masing plot hampir merata.

Tabel 4. Indeks Keanekaragaman, Indeks Keragaman dan Indeks Evennes spesies Lalat (Diptera) di TPA Sukawinatan Palembang Pada tabel 4 (lampiran 1, tabel 4). Dapat dilihat tingkat keanekaragaman di TPA Sukawinatan tergolong rendah, karena pada masing-masing plot ditemukan spesies lalat yang sama, namun jumlah spesies ada yang lebih tinggi sehingga salah satu spesies ada yang dominan (Odum, 1998).

Indeks Dominansi pada plot I sebesar 0,43, Plot II sebesar 0,25, plot III sebesar 0,27, plot IV sebesar 0,16 dan plot V sebesar 0,23. Angka ini menunjukkan pada ke-empat plot memiliki nilai dominansi yang rendah, artinya keberadaan 1 spesies lalat yang ditemukan pada tiap-tiap plot tidak menunjukkan perbedaan jumlah yang signifikan. Meskipun spesies Musca domestica ditemukan lebih banyak daripada spesies lalat yang lain, namun jumlahnya pada kelima plot cukup merata.

Indeks Evenness di lokasi TPA Sukawinatan dikategorikan sedang. Dimana nilai indeks pada tiap plot dengan $0,4<\mathrm{E} \leq$ $0,6=$ Keseragaman Sedang. Spesies lalat ditemukan cukup merata tersebar pada masing-masing plot. Ini disebabkan semua spesies lalat memperoleh makanan dan tempat untuk berkembangbiak di lokasi TPA Sukawinatan Palembang. Hal tersebut 
dapat menjadi salah satu faktor lalat untuk menjadikan habitat hidupnya di TPA karna lalat menyukai tempat- tempat lembab, sampah, serta bau-bau yang busuk (Suraini, 2011).

Tabel 5 Genus Bakteri Pada Spesies Lalat Yang Ditemukan

\begin{tabular}{|c|c|c|c|c|c|c|c|}
\hline \multirow{2}{*}{$\begin{array}{l}\text { Iso } \\
\text { lat }\end{array}$} & \multicolumn{7}{|c|}{ Genus bakteri } \\
\hline & $\begin{array}{l}\text { Pro } \\
\text { vide } \\
\text { ncia }\end{array}$ & $\begin{array}{c}\text { Pr } \\
\text { ote } \\
\text { us }\end{array}$ & $\begin{array}{c}\text { Salm } \\
\text { onell } \\
\text { a }\end{array}$ & $\begin{array}{l}\text { Escher } \\
\text { ichia }\end{array}$ & $\begin{array}{c}\text { Citro } \\
\text { bacte } \\
r\end{array}$ & $\begin{array}{l}\text { Entero } \\
\text { bacter }\end{array}$ & $\begin{array}{c}\mathrm{Vi} \\
\text { bri } \\
\mathrm{o}\end{array}$ \\
\hline $\mathbf{S}_{1}$ & - & + & - & - & - & - & - \\
\hline $\mathbf{S}_{2}$ & + & - & - & - & - & - & - \\
\hline $\mathbf{S}_{\mathbf{3}}$ & - & + & - & - & - & - & - \\
\hline $\mathbf{S}_{4}$ & - & - & + & - & - & - & - \\
\hline $\mathbf{S}_{5}$ & - & - & + & - & - & - & - \\
\hline$S_{6}$ & - & + & - & - & - & - & - \\
\hline $\mathbf{S}_{7}$ & - & - & - & - & + & - & - \\
\hline $\mathbf{S}_{8}$ & - & - & - & - & + & - & - \\
\hline $\mathbf{S}_{9}$ & - & + & - & - & - & - & - \\
\hline $\mathbf{T}_{1}$ & - & - & - & - & - & + & - \\
\hline $\mathbf{T}_{2}$ & - & - & + & - & - & - & - \\
\hline $\mathbf{T}_{3}$ & + & - & - & - & - & - & - \\
\hline $\mathbf{T}_{4}$ & - & - & & - & - & - & + \\
\hline $\mathbf{T}_{5}$ & - & - & - & + & - & - & - \\
\hline $\mathbf{T}_{6}$ & - & - & & - & - & + & - \\
\hline $\mathbf{T}_{8}$ & - & - & + & - & - & - & - \\
\hline
\end{tabular}

Keterangan : (+) : ada

( - ) : tidak ada

Isolat $S_{2}$ dan $T_{3}$ merupakan isolat yang termasuk dalam bakteri berbentuk basil, gram negatif, tidak ada spora, bersifat anaerob fakultatif, bersifat motil, uji katalase dan Methil Red positif, uji sitrat dan Voges Proskauer negatif, uji urea negatif, tidak menghasikan $\mathrm{H}_{2} \mathrm{~S}$ serta fermentasi karbohidrat dengan glukosa menghasilkan asam dan gas. Berdasarkan sifat tersebut setelah dicocokkan pada buku Manual of Determinative Bacteriology $8^{\text {th }}$ edition dan Bergey's Manual of Determinative Bacteriology $9^{\text {th }}$ edition, maka isolat $\mathrm{S}_{2}$ dan $\mathrm{T}_{3}$ termasuk kedalam genus bakteri Providencia.

Isolat $\mathrm{S}_{1}, \mathrm{~S}_{3}, \mathrm{~S}_{6}$, dan $\mathrm{S}_{9}$ memiliki ciri berbentuk cocobasil (kebanyakkan batang lurus), gram negatif, bersifat motil, tidak ada spora, bersifat anaerob fakultatif, uji Methil Red positif, uji katalase positif, uji urea positif, Voges Proskauer negatif, menghasilkan $\mathrm{H} 2 \mathrm{~S}$, fermentasi karbohidrat dengan glukosa menghasilkan asam dan gas. Berdasarkan sifat tersebut isolat $\mathrm{S}_{3}, \mathrm{~S}_{6}$, dan $\mathrm{S}_{9}$ memiliki kemiripan dengan genus Proteus.

Hasil pengamatan pada isolat $S_{4}, S_{5}, T_{2}$, dan $\mathrm{T}_{8}$ menunjukkan ciri-ciri bakteri berbentuk basil, gram negatif, bersifat motil, tidak ada spora, bersifat anaerob fakultatif, uji Methil Red positif, uji katalase positif, uji urea negatif, Voges Proskauer negatif, menghasilkan $\mathrm{H}_{2} \mathrm{~S}$, fermentasi karbohidrat dengan glukosa menghasilkan asam dan gas. Berdasarkan sifat tersebut setelah dicocokkan pada buku Manual of Determinative Bacteriology $8^{\text {th }}$ edition dan Bergey's Manual of Determinative Bacteriology $9^{\text {th }}$ edition, isolat $\mathrm{S}_{4}, \mathrm{~S}_{5}, \mathrm{~T}_{2}$, dan $\mathrm{T}_{8}$ termasuk kedalam genus Salmonella.

Isolat $\mathrm{T}_{5}$ diduga merupakan anggota genus Escherichia, karena memiliki karakter yang mirip dengan genus tersebut. Karakter yang dimiliki isolat $\mathrm{T}_{5}$ yaitu berbentuk batang pendek, gram negatif, bersifat anaerob fakultatif, motil, tidak berspora, tidak memproduksi $\mathrm{H}_{2} \mathrm{~S}, \quad$ mampu memfermentasikan glukosa, mampu memfermentasikan laktosa, katalase positif, reduksi Methil Red positif, uji Voges Proskauer negatif serta tidak menggunakan sitrat sebagai sumber energi.

Isolat $\mathrm{S}_{7}, \mathrm{~S}_{8}, \mathrm{~T}_{7}$ memiliki karakter yang mirip dengan genus Citrobacter, yaitu berbentuk batang pendek, mampu menfermentasikan glukosa, gram negatif, bersifat anaerob fakultatif, motil, tidak berspora, tidak memproduksi $\mathrm{H} 2 \mathrm{~S}$, katalase positif, reduksi Methil Red positif, uji Voges Proskauer negatif serta menggunakan sitrat sebagai sumber energi.

Hasil pengamatan pada isolat $\mathrm{T}_{1}$ dan $\mathrm{T}_{6}$ memiliki karakter berbentuk basil, gram negatif, bersifat anaerob fakultatif, motil, tidak berspora, tidak memproduksi $\mathrm{H}_{2} \mathrm{~S}$, mampu memfermentasikan glukosa, mampu memfermentasikan laktosa, katalase positif, reduksi Methil Red negatif, uji Voges Proskauer positif serta menggunakan sitrat sebagai sumber energi. Karakter ini setelah 
dicocokkan pada buku Manual of Determinative Bacteriology $8^{\text {th }}$ edition dan Bergey's Manual of Determinative Bacteriology $9^{\text {th }}$ edition, isolat $\mathrm{T}_{1}$ dan $\mathrm{T}_{6}$ memiliki kemiripan dengan genus Enterobacter.

Isolat $\mathrm{T}_{4}$ memiliki karakter yang mirip dengan genus Vibrio, yaitu berbentuk basil, gram negatif, bersifat anaerob fakultatif, motil, tidak ada spora, tidak memproduksi $\mathrm{H}_{2} \mathrm{~S}$, reduksi Methil Red negatif, Voges Proskauer negatif, katalase positif, fermentasi glukosa menghasilkan asam tanpa gas.

\section{SIMPULAN}

1. Spesies di lokasi Tempat Pembuangan Akhir Sampah (TPA) Sukawinatan Palembang ditemukan 5 spesies lalat yaitu Musca domestica, Chrysomya megacephala, Lucilia sp, Sarcophaga sp dan Fannia sp. Sedangkan spesies lalat di lokasi Pasar Induk Jakabaring Palembang ditemukan 4 spesies lalat, yaitu Musca domestica, Chrysomya megacephala, Lucilia sp, dan Fannia $\mathrm{sp}$.

2. Bakteri yang ditemukan pada spesies lalat di lokasi Tempat Pembuangan Akhir Sampah (TPA) Sukawinatan Palembang ditemukan bakteri dari genus Proteus, Salmonella, Providencia dan Citrobacter. Sedangkan Bakteri yang ditemukan pada spesies lalat di lokasi Pasar Induk Jakabaring Palembang ditemukan bakteri dari genus Salmonella, Providencia, Citrobacter, Escherichia, Vibrio dan Enterobacter.

\section{Ucapan Terima Kasih}

Ucapan terima kasih disampaikan kepada Program Studi Pengelolaan Lingkungan Jurusan Biologi Lingkungan Pasca Sarjana Universitas Sriwijaya. Universitas Andalas Fakultas Teknik Jurusan Teknik Lingkungan, atas bantuannya dalam penerbitan jurnal penelitian ini.

\section{DAFTAR PUSTAKA}

Alfiani D. 2011. Karakteristik Lokal Sebagai Studi Tentang Keberlanjutan Tempat Pembuangan Akhir Sampah Di Daerah perkotaan. [Tesis]. Program Magister Ilmu Geografi Universitas Indonesia.

Amelia S. 2005. Vibrio Cholerae. Fakultas Kedokteran. Universitas Sumatera Utara Digitized By USU digital Library.: $17 \mathrm{hlm}$ (Dipublikasikan).

Azwar, Azrul. 1995. Pengantar Ilmu Kesehatan Lingkungan. Jakarta Mutiara Sumber Widya.

Bahrin D, Anggraini D, dan Pertiwi MB. 2011. Pengaruh Jenis Sampah, Komposisi Masukan Dan Waktu Tinggal Terhadap Komposisi Biogas Dari Sampah Organik Pasar Di Kota Palembang. Fakultas Teknik Universitas Sriwijaya Prosiding Seminar Nasional AVoER ke-3; Palembang, 26-27 Oktober 2011.

Benson, H. J., 2002. Microbiological Application: Laboratory Manual in General Microbiology. Eighth Edition. Mc. Graw-Hill. Nort America : xi + $478 \mathrm{hlm}$.

Borror, D.J., C.A. Triplehom., and N.F Jonhson, 1992. An introduction to the insect terjemahan Partosoedjono, S dan Mukayat, D.B. Gajah Mada Universitas Press. Yogyakarta: xviii+1009 hlm.

Buchanan, R.E and Gibbons, N.E 1974. Bergey's Manual of Determinative Bacteriology. Eight Edition. A Waverly Company. USA: xxiii+920 hlm.

Butler, J.F., A.G. Maruniak., F. Meek., and J.E. Maruniak. 2010 . Wild Florida house flies (Musca domestica) as carrier of pathogenic bacteria. Florida Entomologist 93(2). 218-223.

Bontong AR, Mahatmi H, Suada IK. 2012. Kontaminasi Bakteri Escherichia coli Pada Daging Se'i Sapi Yang Dipasarkan Di Kota Kupang. Indonesia Medicus Veterinus 1(5) : $699-711$.

Capuccino, J.G and Sherman, N. 2008. Microbiology a Laboratory Mannual. Eighth edition. The 
Benjamin/Cummings Publish.

Company Inc,California. USA: xvii+569 hlm.

Damanhuri E dan Padmi T. 2010. Pengelolaan Sampah. Diktat Kuliah Teknik Lingkungan. Program Studi Tenik Lingkungan. ITB: $i x+30 \mathrm{hlm}$. (tidak dipublikasikan).

Darmawati S. 2005. Identifikasi Dan Hitung Jumlah Bakteri Kontaminan Pada Lalat Musca domestica Berdasarkan Lokasi Penangkapan Di Rumah Sakit Bhayangkara Semarang. Jurnal Unimus 2 ( 2) : 77-84.

Dinas Kebersihan Kota Palembang. 2012. Komposisi Sampah Kota Palembang.

Dinas Kebersihan Kota Palembang. 2014. Volume Sampah TPA Sukawinatan Palembang.

Elina H. 2007. Pola Penanganan Tempat Pembuangan Akhir (TPA) Dan Pengaruhnya Terhadap Kesehatan Masyarakat Di TPA Sukajaya Kecamatan Sukarami. Tesis. Palembang: Program Pascasarjana Universitas Sriwijaya.

Febrita A. 2008. Struktur Komunitas Arthropoda Dalam Tanah Pada Areal Perkebunan Karet (Hevea bransiliaensis) Di Kec. Inuman Kab. Kuantan Singingi-Riau. Jurnal Pilar Sains 7 (1): 37-45.

Fidiawati L dan Sudarmaji. 2013. Pengelolaan Tempat Pemrosesan Akhir Sampah Kabupaten Jombang Dan Kesehatan Lingkungan Sekitarnya. Jurnal Kesehatan Lingkungan 7 (1): 45-53

Hadioetomo, R.S. 1993. Mikrobiologi Dasar dalam Praktek : Teknik dan Produser Dasar Laboratorium. PT. Gramedia. Jakarta: vi+163 hlm.

Haribi R, dan Yusron K. 2008. Pemeriksaan Escherichia coli Pada Air Bak Wudhlu 10 Masjid Di Kecamatan Tlogosari Semarang. Jurnal Kesehatan 3(1) : 22-27.

Hastutiek P dan Fitri LE. 2007. Potensi Musca Domestica linn. Sebagai vektor beberapa penyakit. Jurnal Kedokteran Brawijaya 23(3) : 125-136.

Hestiningsih R. 2004. Perbandingan bakteri kontaminan Pada lalat Chrysomya Megacephala dan Musca Domestica di tempat pembuangan sampah akhir piyungan, bantul, Yogyakarta. Jurnal Unimus 1(2) : 51-58.

Holt JG, Krieg NR, Sneath PHA, Staley JT, and Williams ST. 1994. Bergey's Manual of Determinative Bacteriology. Ninth Edition. A Waverly Company. USA: xviii+787 hlm.

Ikhsandri, Ilmiaty SR, dan Septi N. 2014. Kajian Infrastruktur Pengolahan Sampah di Kawasan Berkembang Jakabaring Kelurahan 15 Ulu Kota Palembang. Jurnal Teknik Sipil dan Lingkungan 2(1) : 137-145.

Ilmiah, Sukenda, Widanarni dan Harris E. 2012. Isolasi Dan Karakterisasi Vibrio Patogen Ikan Kerapu Macan Epinephelus fuscoguttatus. Jurnal Akuakultur Indonesia 11(1) : 28-37.

Irianto K. 2006. Menguak Dunia Mikrobiologi. Jilid I. Bandung: xiii + $256 \mathrm{hlm}$.

Jutono, S. Hartadi, S. Suhadi dan Soesanto. 1973. Pedoman Praktikum Mikrobiologi Umum Untuk Perguruan Tinggi. Departemen Mikrobiologi Fakultas Pertanian Universitas Gadjah Mada. Yogyakarta: xii $+232 \mathrm{hlm}$.

Kalshoven LGE. 1981. Pest of Crops in Indonesia. Revised and Translated by van der Laan. PT. Ichtiar Baru-van Hoeven. Jakarta.

Laksmita AS, Watiniasih NL, Junitha IK. 2013. Prediksi Lama Kematian Berdasarkan Keberadaan Serangga Genus Lucilia (Calliphoridae) Pada Bangkai Mencit (Mus musculus) di Lokasi Hutan Mangrove. Jurnal Biologi 17(1) : 1-5.

Lay BW. 1994. Analisis Mikroba di Laboratorium. Edisi I. PT RajaGrafindo Persada. Jakarta: xviii+168 hlm.

Lilies C. 1991. Kunci Determinasi Serangga. Kanisius. Jakarta: xii+223 hlm.

Maryuni SRM. 2008. Spesies Lalat Di TPA/TPS Dan Berbagai Jenis Sampah Kota Baturaja Dalam Variasi Musim Serta Pemeriksaan Parasit Usus Pada Spesies Lalat. Tesis. Program Pascasarjana Universitas Sriwijaya.

Melani A, Niswah FI, Purnawati N, Sari MA. 2014. Makalah Gangguan Penyakit Sampah Melalui Vektor 
Lalat. Ilmu Kesehatan Masyarakat. Universitas Negeri Semarang. $17 \mathrm{hlm}$.

Nazni, W.A., Seleena, B., Lee, H.L., Jeffery, J., T. Rogayah, T.A.R. and Sofian, M.A. 2005. Bacteria Fauna From The House Fly, Musca domestica (L.). Institute For Medical Research Kuala Lumpur. Journal of Tropical Biomedicine 22(2): 225-231.

Odum, E.P. 1998. Dasar-Dasar Ekologi. Terjemahan Tjahjono Samigan. Edisi ke-4. Gadjah Mada University Press Yogyakarta: xv+697 hlm.

Prabowo, K. 1992. Petunjuk Praktis Pengendalian Vektor dan Binatang Pengganggu. Jakarta: Depkes RI.

Prihastini L. 2011. Dampak Tempat Pembuangan Akhir (TPA) Sampah Winongo Terhadap Kualitas Lingkungan Hidup. Jurnal Penelitian Kesehatan Suara Forikes 2(1) : 7-15

Putra NS. 1994. Serangga di Sekitar Kita. Penerbit Kanisius. Jakarta: ix +117 hlm.

Putri PY, Jasmi, Armein, dan Zeswita L. 2013. Keanekaragaman Lalat (Cyclorrapha: Diptera) Pada Lokasi Penjualan Ikan Segar Di Kota Padang. Universitas Andalas Padang. Jurnal of Biological Education. 2(2) : 1-6.

Rozendaal, JA. 1997. Vector Control. Methods for Use by Individual and Communities. Geneva: WHO.

Santi, DN. 2001. Manajemen Pengendalian Lalat. Fakultas Kedokteran. Universitas Sumatera Utara Digitized By USU digital Library.: $5 \mathrm{hlm}$ (Dipublikasikan).

Sariadji K, Sunarno, Nelly P, Wati M, Khariri, Sundari N.S dan Amalia N. 2013. Evaluasi Medium Pengayaan Vibrio Cholerae Untuk Diagnosis Kolera Menggunakan Immunochromatographic Strip Test. Bul. Penelit. Kesehatan 41(1): 11 - 17

Sayono, Mardhotiltah S dan Martini. 2004. Pengaruh Aroma Umpan Dan Warna Kertas Perangkap Terhadap Jumlah Lalat Yang Terperangkap. Jumal Litbang Universitas Muhammadiyah Semarang 2(1): 30-36.

Setiawan SD dan Farida H, 2010. Faktor Risiko Kolonisasi Enterobacteriaceae Pada Nasofaring Dewasa. Karya Tulis Ilmiah. Program Pendidikan
Sarjana kedokteran Fakultas Kedokteran Universitas Diponegoro. $17 \mathrm{hlm}$ (Dipublikasikan)

Sukontason KL, Bunchoo M, Khantawa B, Piangjai S, Rongsriyam $\mathrm{Y}$ and Sukontason K. 2007. Comparison Between Musca domestica and Chrysomya megacephala As Carriers Of Bacteria In Northern Thailand. Journal Trop Med Public Health $38(1): 38-44$.

Suraini. 2011. Jenis - Jenis Lalat (Diptera) Dan Bakteri Enterobacteriaceae Yang Terdapat Di Tempat Pembuangan Akhir Sampah (TPA) Kota Padang [Tesis]. Padang: Program Pascasarjana Universitas Andalas.

Soegianto A. 1994. Ekologi Kuantitatif Metode Analisis Populasi dan Komunitas. Penerbit Usaha Nasional. Surabaya: ix $+173 \mathrm{hlm}$

Wahyu N, Suharto G, dan Kirana S. 2009. Perbedaan Genus Larva Lalat Pada Bangkai Tikus Wistar Diletakan Di Darat, Air Tawar Dan Air Laut. Laporan Akhir Penelitian Karya Tulis Ilmiah. Fakultas Kedokteran Universitas Diponegoro. Semarang: $29 \mathrm{hlm}$.

Yuriatni. 2011. Keanekaragaman Lalat (Cyclorrapha: Diptera) Dan Parasit Usus Yang Dibawanya Di Kabupaten Dan Kota Solok Sumatera Barat . [Tesis]. Padang: Program Pascasarjana Universitas Andalas. 